УДК: 316.334.23

JEL Classification: L 26

\author{
К. БОРИЦЬКИЙ, \\ магістр ділового адміністрування, \\ генеральний директор TOB "Benteler Distribution Poland", \\ м. Домброва-Гурнича, Польияа
}

\title{
Теоретичні основи соціальної відповідальності підприємства
}

В статті розкрито теоретичні основи соиіальной відповідальності підприємства, розелянуто тлумачення терміна "сочіальний". Проаналізовано моделі сочіальної відповідальності підприсмства та системи сочіальної відповідальності. Доведено, що схема системи соціальной відповідальності підприсмств працюватиме ефективно та сприятиме реалізацій цілей організацій, якио вона матиме риси відкритої системи, якій притаманна взасмодія з оточенням. Водночас із цим, згідно із системним напрямком сучасних теорій управління, сприймаючи підприсмство як однорідну, иільову систему, слід пам 'ятати, щзо всі внутрішні дій, які проходять в одному елементі системи, мають наслідки для інших іл елементів.

Ключові слова: бізнес, корпоративна сочіальна відповідальність, модель сочіальної відповідальності, підприсмство, стратегія.

Постановка проблеми в загальному вигляді та її зв'язок із важливими науковими та практичишми завданиями. Ще ніколи корпоративна соціальна відповідальність (КСВ або CSR - 3 анг.: corporate social responsibility) не займала таку високу позицію помгіж прюритетів політики нідприємств, як у наш час. У черговий раз фінансова криза та ії вплив на глобальну економіку довели, що стабільність загальносвітового ринку залежить від відповідальної поведінки, моделей збалансованого ведення господарсыкої діяльності, активного управління впливом бізнесу (підприємств) на соціальне життя та від чинного законодавства. На глобальну соціальну поведінку корпорацій впливають також проблеми, пов'язапі зі змінами світового клімату та поглибленням соціальної нерівності. Як на глобальному, так і галузевому рівні наявний величезний попит на соціальну політику.

Необхідність залучення бізнесу до суспільних та соціальних питань пояснюється тим, що для зміцнення стабілізації та відтворення багатства впродовж тривалого часу потрібний новий глобальний соціальний договір між бізнесом, урядом та суспільством. Це стає дедалі очевиднішим на рівні нідприємств.

Вищезазначене обумовлює актуальність досліджень теоретичних аспектів соціальної відповідальності нідприємств.

Аналіз класичних конщепцій соціашної відиовідальності бізнесу. Концепція соціальної відповідальності, яка походить від так званої "теорії стекхолдерів" (анг. stakeholders theory), виникла у США. Дослідження соціальної відповідальності в Свроні розпочалися в Німеччині із середини XIX ст., коли домінувала модель Бісмарка. Європейські держави взяли на себе певні зобов'язання перед працівниками, споживачами та іншими групами, шо складали соціальне оточення підприємства. Натомість відсутність подіб̈ної ролі держави у США привела до критики налаштованих на прибуток нідприємств. Ідея, згідно 3 якою бізнес має зобов'язання перед суснільством, поширювалась в 50 -х роках ХХ ст. Г. Р. Бові. До цієї ідеї критично ставився М. Фрідман, не беручи під сумнів питання соціальної відповідальності підприємства, але обмежуючи їі передусім власниками (пайовиками), які вкладають свій канітал. В свою чергу, І. Ансофф та Р. Стюарт створили основи теорії “зацікавлених сторін”, згідно з якою підприємство має зобов'язання також перед іншими групами, а не тільки перед власниками. ємства.

Мета статті - розкрити теоретичні основи соціальної відповідальності підпри-

Виклад основного матеріату з повним обгрунтуванням отриманих наукових результатів. Термін “соціальний” часто вживається в мові польського законодавства. Він застосовується у Конституції Республіки Польща в ст. 2, яка визначає Республіку

(с) К. Борипький, 2017 
Польща як державу, що здійснює принщипи соціальної справедливості. Соціальна справедливість тлумачиться як рівне ставлення до осіб, які мають характерну рису, вагому для певної категорії осіб [7, с. 150].

Термін “соціальний” застосовується також на установчому рівні. Він має велике значення в приватному законодавстві з огляду на клаузулу принципів соціального співіснування.

Термін "соціальний" є багатозначним, однак у юридичному контексті він означає необхідність брати до уваги, окрім буквального розуміння цього слова, соціальний контекст, в якому ця норма функцюнує. Подібно соціальному впливу бізнесу, який відбувається на юридичному рівні, він спричиняє необхідність звертати увагу на вплив дін̆ нідприємця на його оточення. Термін “соціальний" $є$ синонімом слова "суспільний".

Другий складовий елемент соціальної відповідальності підприємств - це термін “відповідальність", який у “Словнику польської мови” тлумачиться таким чином:

- моральний або юридичний обов'язок відповідати за свої або чиїсь вчинки;

- прийняття обов'язку дбати про когось або шось.

В свою чергу, термін "відповідальний" означає:

- готовий понести наслідки за свої вчинки;

- який має обов'язок стежити за чимось;

-

- який спричиняє якийсь стан або процес [9, с. 578].

Для порівняння, “Новий тлумачний словник української мови”" пояснює термін "відповідальність" як “"покладений на когось або взятий на себе обов' язок відповідати за певну ділянку роботи, справу, за чиїсь дії, вчинки, слова", натомість “відповідальний” - це той, "на якого покладена відповідальність за яку-небудь ділянку роботи, справу тощо" $[10$, Т. 1, с. 317].

Термін "відповідальність" не можна ототожнювати з його юридичним значенням. Відповідальність у значенні предметної конщепції означає позитивні дії підприємця. Підтвердженням може бути вживання в цьому контексті в англійській мові слова "responsibility" (позитивне зобов'язання) замість “liability" (юридична відповідальність у зв'язку зі здінссненням вчинку).

Термін “соціальна відповідальність" належить відповідно до досліджуваної концепції до бізнесу. За "Словником польської мови" бізнес - це торгове або виробниче починання, яке приносить прибуток, в розмовному стилі також "фірма (підприємство), яка цей проект здійснює” [9, с. 54]. Отже, цей термін не має юридичного характеру. Його відповідником буде поняття “підприємець", тобто фізична особа, юридична особа та організаційна одиниця (яка не $\epsilon$ юридичною особою і якій установа надає правоздатність), яка від свого імені веде господарську або трудову діяльність. У первинному англін̆ському варіанті вживається слово “corporate”. В прямому перекладі маємо відтак справу із корпоративною соціальною відповідальністю, соціальною відповідальністю корпорацій. Це вказує на те, що соціальна відповідальність у мовних значеннях стосується передусім великих економічних суб' єктів, зокрема міжнародних. Таке розуміння соціальної відповідальності бізнесу дозволяє також, пояснюючи їі нормативний зміст, використову вати приншипи "corporate governance". Водночас потрібно визнати, що соціальна відповідальність бізнесу стосується підприємця як такого, без огляду на його величину [3, с. 27-34].

КСВ (корпоративна соціальна відповідальність) не має чіткого визначення ні в літературі, ні в практичній діяльності. Визначення КСВ подаються в різних інтерпретаціях [2, с. 20]. Під час участі у семінарах і конференціях та при ознайомленні 3 інформацією ЗМІ найчастіше зустрічаємося з визначенням "КСВ". Відповідальний бізнес шукає синергії між трьома сферами діяльності підприємства: економічною, екологічною та соціальною.

Це можна описати приншипом “3Р” від англійського визначення "People - Planet Profit". Основою КСВ є відповідальна та етична поведіика бізнесу стосовно всіх соціальних груп, на які він впливає через його діяльність, при якомога дбайливому ставленні до навколишнього середовища. Тут ідеться про те, щоб бізнес ставав кращим, тобто брав на себе добровільні зобов'язання, наприклад стосовно місцевих громад та середовища, а також обмежував можливість виникнення негативних явищ, як1 можуть загрожувати функціонуванню підприємства. 
Дж. Мак Гуір, даючи загальне визначення соціальної відповідальності, стверджує, що корпорації несуть не тільки властиву їм економічну та юридичну відповідальність, а й певну відповідальність перед суспільством у цілому. В Польщі для визначення терміна "соціальна відповідальність бізнесу" зазвичай вживається акропім "CSR", від англійського "corporate social responsibility". Він $є$ найбільш поширеним визначенням. В англійській мові зустрічаються й інші терміни, наприклад "corporate sustainability", "corporate responsibility", "corporate accountability", "corporate citizenship", а також найбільш місткий терміи "sustainable development" (зрівноважений розвиток). Але в усіх випадках ідеться про діяльність, яка має зробити (рірму ще кращою [5, с. 13].

Термін "соціальна відповідальність бізнесу" згадується також у “Зеленій Книзі" Європейської комісії від 18 липня 2001 р. як конщепція, згідно 3 якою нідприємства при здійсненні діяльності добровільно враховують соціальні та екологічні аспекти. Соціальна відповідальність бізнесу - це процес, завдяки якому нідприсмства управляють відносинами з різними зацікавленими сторонами, які можуть мати реальний вплив на їхню діяльність. Таким чином, КСВ повинна сприйматися як інвестиція, а не витрати, так само як управліиня якістю.

Світова рада бізнесу у справах усталеного розвитку пояснює соціальну відповідальність бізнесу як безперервне зобов'язання бізнесу щодо етичної поведінки та сприяння економічному розвитку при одночасному покращенні якості життя робочої сили та іiї сімей, а також місцевої громади і суспільства в цілому, або як зобов'язання бізнесу щодо сприяння усталеному економічному розвитку, снівпраці з працівниками, їхніми сім'ями, місцевою громадою та суспільством у цілому для покращення якості ïх життя [3, с. 26-27].

В 90-х роках минулого століття в США сформувалась модель соціальної відповідальності як “доброго громадянина", яку запропонував А. Б. Керолл. Окрім прийнятої раніше економічної та юридичної відповідальності, вона брала до уваги етичний критерій бізнесу, а також ввела поняття “соціальна діяльність для оточення".

Модель соціальної відповідальності охоплює чотири сфери відповідальності, використовуючи піраміду потреб Маслоу [8, с. 29-31]. Першою, найважливішою сферою автор теорії вважає економічну ві дповідальність, потім - юридичну і етичну. Благодійна відповідальність - це остання сфера, проте найбільш помітна.

А. Б. Керолл основою соціальної відповідальності вважав сферу економічної відповідальності. На його думку, тільки корисне ведення бізнесу дозволяє приймати інші види відповідальності. Як другу сферу він окреслив юридичну відповідальність, вважаючи, що нідприємство, яке прагне до досягнення прибутку, має поводитися законно. Наступну сферу становить моральна відповідальність, причому в випадку нідприємства можна говорити про етичну відповідальність, яку розуміємо як дотримання правил, прийнятих суснільством. Етична відповідальність стосується ведення діяльності у гідний, справедливий спосіб, не шкодячи іншим. Останньою сферою, яка знаходиться на верхівці ніраміди, є благодійна відповідальність, яка, ніби вершина льодяної гори: дуже маленька, проте дуже помітна. Благодійна відповідалыпість пов'язана зі здійсненням або фінансуванням дій для вирішення окремих соціальних проблем у вигляді спонсорства, благодійної діяльності, програм нідтримки місцевої громади. Модель соціальної відповідальності за А. Б. Кероллем показано в таблиці.

Модель соціальної відповідальності за А. Б. Кероллем

\begin{tabular}{|c|c|c|}
\hline $\begin{array}{c}\text { Коло } \\
\text { відповідальності }\end{array}$ & $\begin{array}{l}\text { Ступінь реалізації } \\
\text { відповідальності }\end{array}$ & $\begin{array}{c}\text { Об'єкт } \\
\text { відповідальності }\end{array}$ \\
\hline 1 & 2 & 3 \\
\hline $\begin{array}{l}\text { Економічна } \\
\text { відиовідальність }\end{array}$ & вимагається & $\begin{array}{l}\text { - рентабельність; } \\
\text { - максимізація прибутків; } \\
\text { - мінімізація витрат; } \\
\text { - ефективні стратегії; } \\
\text { - иолітика розподілу }\end{array}$ \\
\hline
\end{tabular}




\begin{tabular}{|c|c|c|}
\hline \multicolumn{3}{|r|}{ Продовження табл. } \\
\hline 1 & 2 & 3 \\
\hline $\begin{array}{l}\text { Юридична } \\
\text { відповідальність }\end{array}$ & вимагається & $\begin{array}{l}\text { Дотримання закону у: } \\
\text { - веденні господарської діяльності } \\
\text { - захисті середовища; } \\
\text { - охороні споживача у трудовому } \\
\text { праві: } \\
\text { - бізнесових зобов'язаннях }\end{array}$ \\
\hline $\begin{array}{l}\text { Етична } \\
\text { відповідальність }\end{array}$ & очікувана & $\begin{array}{l}\text { - дотримання етичних принцинів; } \\
\text { - відмовлення від нечесної } \\
\text { поведінки; } \\
\text { - етичне лідерство; } \\
\text { - етичні програми }\end{array}$ \\
\hline $\begin{array}{l}\text { Благодійна } \\
\text { відповідальність }\end{array}$ & бажана & $\begin{array}{l}\text { - спонсорська допомога освіті, } \\
\text { культурі, спорту; } \\
\text { - програми для місцевої громади; } \\
\text { - благодійна діяльність; } \\
\text { - корпоративне волонтерство }\end{array}$ \\
\hline
\end{tabular}

Джерело: [4, с. 35]

В підході А. Б. Керолла основою соціальної відповідальності є рентабельність підприємства (after profit obligation). Інші види відповідальності виникають тоді, коли підприємство досягає економгічної ефективності. Такий підхід правильний, якщо брати до уваги прюритет рентабельності у порівнянні з благодійною діяльністю. оскільки отримання рентабельності відкриває шлях до благодійності. Натомість важко погодитися з ідеєю схвалення рентабельності незважаючи на юридичні та етичні принципи.

Чергова модель соціальної відповідальності (before profit obligation), запропонована I. Ч. Кангом та Д. Дж. Вуд, віддавала прюритет моральним якостям [6, с. 414]. Відповідно до цієі моделі кожна корпорація зобов'язана дотримуватися моральних та соціальних норм на кожному етапі ії діяльності. Це означає, шо прибуток, отриманий iз порушенням етичних норм, не може бути морально виправданий. Варто наголосити, що не кожна корпорація повинна бути постійно працюючою, а тільки та, що дотримується етичних норм.

У підході цих авторів найважливішим є етичний чинник, який і має санкціонувати діяльність підприємства. Підприємство зобов язане брати до уваги очікування зацікавлених сторін і трактувати іхні цілі так само, як і свої. Якщо такий принцип виконується, підприємство отримує свободу вибору способу отримання прибутків. Тільки після виконання юридичних та етичних умов підприємство може збільшувати прибутки та здійснювати благодійну діяльність. Благодійна діяльність у сприйнятті Канга і Вуд охоплює добровільну участь зацікавлених сторін підприємства, а також значно ширші дії, що стосуються глобальних проблем [1, с. 40-42|.

К. Дейвіс обгрунтовує соціальну відповідальність підприємств низкою тез:

$>$ соціальна відповідальність походить від сили суспільства, яке вимагає від підприємств більшої відповідальності за соціальні умови, які виникають 3 розвитком їхньої діяльності;

$>$ підприємство повинно працювати як прозора система, відкрита для сигналів із боку суспільства;

$>$ в процесі прийняття рішень стосовно будь-яких дій, виробів чи послуг підприємство повинно вираховувати їх вартість та соціальну користь;

$>$ соціальна вартість діяльності підприємства в результаті переходить на споживачів:

> підприємства та громадяни зобов'язапі брати активну участь у вирішенні соціальних проблем, які не лежать поза безпосередньою сферою їх діяльності;

Прийняття підприємствами такої відповідальності вимагає:

$>$ залучення соціальних цілей до системи стратегічних цілей;

$>$ запровадження методів вимірювання та критеріїв оцінювання реалізації соціальних цілей; 
> вимірювання вартості та прибутків реалізації соціальних програм;

$>$ розроблення та розповсюдження для зацікавлених сторіи звітів про реалізацію завдань із соціальної відповідальності підприємств [1, с. 42-43].

Соціальна відповідальність підприємства вимагає балансування цілей різних груп, які функціонують як усередині підприємства, як і в його оточенні. 3 огляду на зміни оточення підприємство входить у мережу соціальних відносин, тому формування правильних відносин із зацікавленими сторонами гарантує їх прихильність при реалізації цілей підприємства. Звідси необхідність прийняття підприємством рішень, спрямованих на виявлення основних зацікавлених сторін, діагностування іхніх очікувань та включення реалізації цих очікувань до цілей підприємства. Добровільне прийняття відповідальності підприємством - це побудова та реалізація стратегії соціального заангажування, яке виходить поза юридичні зобов'язання.

Соціальну відповідальність підприємства можна розуміти як відповідальність за зобов'язання, прийняті в результаті його соціального співіснування. Отже, така відповідальність виникає внаслідок соціальної волі, що змушує підприємства працювати у певний спосіб. Оскільки підприємства створюються з метою досягнення інтересів власників, вони залежать від моральної оцінки їх діяльності зацікавленими суб' єктами, так званими носіями ризику (stakeholders). Дискусію викликає питання, хто $є$ носієм ризику. В ринковій економіці підприємство самостійно визначає цілі та забезпечує кошти для їх досягнення, керуючись принципом прибутковості. Самостійне визначення цілей та пошуку коштів для їх реалізації вимагає від підприємства відповідальності за здійснення цілей перед усіма групами, зацікавленими в його діяльності [1, с. 43].

З наведеної вище вибірки підходів до тлумачення соціальної відповідальності підприємства слідує, що однозначної думки стосовно сутності соціальної відповідальності підприємства на сьогодні немає, а ії теоретичні обговорення триватимуть і надалі.

Так, в результаті досліджень на місце доктрини соціальної відповідальності (social responsibility, CSR) прийшла концепція соціального реагування (social responsiveness, CSR2), а далі - концепція соціального внеску (corporate social performance, CSR3). Згідно з останньою, структурно-оргапізаційпі рішення визначають вид і обсяг соціального реагування, а відтак спосіб, в який підприємство трактує соціальні питання, що в результаті впливає на структуру вироблених підприємством вартостей та послуг і на конкретні способи його функціонування.

У зв'язку з потребою підприємств у проектуванні та реалізації стратегії соціального внеску дослідники створили інтегровані моделі соціально відповідальної поведінки підприємств. Дослідження показали, що до найбільш відомих моделей цього типу належать тривимірні моделі С. Л. Вартіка та П. Л. Кохрена, а також Д. Дж. Вуд. Кожна модель має три виміри:

$>$ принципи, які віддзеркалюють актуальний стан науки в галузі соціальної відповідальності підприємств;

$>$ процеси, тобто реакції підприємства на соціальні проблеми;

> політику, тобто модель соціально-відповідального управління.

С. Л. Вартік та П. Л. Кохрен перші звернули увагу на те, що підприємство повинно перейти від звичайної ідентифікації соціальних проблем до управління ними. Тому вони взялися до розроблення практичної моделі управління. Творячи таку модель, вони спробували відповісти на такі запитання: яка організаційна структура $\epsilon$ найкращою для реалізації прийнятої мети; яку роль повинно відіграти управління у виборі найкращого способу реагування корпорації на соціальні проблеми; які зміни в системі винагород забезпечать найбільш ефективну реакцію на соціальні проблеми; яким способом інституціоналізувати та інтегрувати соціальну політику із загальною політикою та стратегією фірми.

В конструкції презентованої моделі її творці використовують згадану раніше піраміду соціальної відповідальності корпорації А. Б. Керолла, трактуючи компоненти піраміди в моделі як приншипи.

Вартік та Кохрен, подібно до Керолла, вважають, що рентабельність є головним приншипом відповідальності кожної індивідуальної корпорації. На цій основі можна припустити, що корпорації, які досягають нижчого прибутку, ніж середньоочікуваний 
рівень, не будуть обмежені необхідністю бути соціально відиовідальними, а фірми, які взагалі не отримують прибутку, можуть бути зовсім вільними від яких-небудь соціальних зобов 'язань, а відтак можуть ігнорувати всі моральні принципи та балансувати на межі закону, оскілыки їх основне завдання - пошук способів досягнення прибутку. Однак наявність лише однієї мети - максимізації прибутку, нідштовхує корпорації до проявів "хижоі” поведінки в країнах, що розвиваються, та найменш економічно розвинутих країнах, а отже до різноманітних загроз для глобальної економіки.

Дослідження показали, шо для досягнення стану стратегічного обгрунтування соціальної відповідальності варто, шоб ідея КСВ мала стратегічний вимір. Вихідними пунктами у формуванні соціальної відповідальності є місія та стратегічні цілі підприємства. Ці документи повинні містити “декларації" стосовно КСВ. Згадані зобов' язання мають відображатися далі в стратегії підприємства, в якій важливо врахувати три аспекти, безпосередньо пов 'язані з ідеєю соціальної відповідальності. Йдеться про необхідність переконати клієнтів та зацікавлені сторони, що фірма прагнутиме (між іншим через помноження власних прибутків) до збільшення користі оточенню підприємства.

Це має виправдання в так званому економічному аспекті. Багато науковців (у тому числі М. Фрідман) вважають такий підхід найважливішим з огляду на цілі діяльності фірми. Декларація про поведінку у взаємодії не тільки з вимогами чинного законодавства, а і з моральними стандартами - це чергова важлива мета, до якої слід прагнути. В нинішньому опрацюванні вона вказана як етичний аспект. Доповненням загальної стратегії є також схвалення положень щодо захисту природного середовища, що входить до складу екологічного аспекту

Водночас фірма повинна окреслити всі елементи в ланцюгу цінностей - від кунівлі сировини, виробництва, пакування, транспортування, продажу і аж до так званого кінця життєвого циклу виробу (який охоплює, наприклад, рециклінг). Ідеться про те, шоб не декларувати широку відповідальпість перед усіма можливими зацікавленими сторонами, а назвати кілька ключових сторін - так, щоб визначені перед ними завдання могли бути реально здійснені. Кожна організація має свійі власний, унікальний набір ключових питань, пов'язаних, наприклад, із захистом природного середовища, соціальними справами та здоров'ям. Та спочатку вона має оцінити, які $з$ цих питань несуть із собою найбільше загроз або можуть бути використані як джерело економічної користі.

На цьому етапі фірма може також оцінити витрати пального, рівень емісії; уточнити, чи не утворюються під час виготовлення продукції якісь токсичні речовини, небезпечні для людей та природного оточення; перевірити, чи можна ефективніше управляти відходами або зменшити витрати води чи рівень шуму, і уточнити, чи не заважас він мешканщям, які проживають біля виробництва. Слід проаналізувати, в яких умовах працює колектив, які стандарти роботи, чи достатньо фірма дбає про безпеку, здоров'я та розвиток працівників. Потрібно подивитися не тільки на власну операційну діяльність, а й подумати про те, що відбувається з виробом фірми, коли він доставлений до споживача. Відповідальність виробника не закінчується в момент виготовлення товару. Адже може бути так, що він надходить на ринок в упаковці, яка перетворюватиметься на відходи, небезпечні для природного середовища.

Висновки. Для того, щоб наведена схема системи соціальної відповідальності підприємств працювала ефективно та допомагала в реалізації цілей організації, вона повинна мати риси відкритої системи, що взаємодіє 3 оточенням. Водночас, згідно із системним напрямком сучасних теорій управління, сприймаючи підприємство як однорідну, цільову систему, слід пам'ятати, що всі внутрішні дії, які проходять в одному елементі системи, мають вплив на інші ііі елементи.

Вже на початку створення підприсмства власникові важливо проаналізувати, крок за кроком, які видимі на невидимі загрози для фірми супроводжують їі негативний вплив на зацікавлені сторони, а також дослідити, які користі може принести позитивна діяльність. Такий аналіз дозволяє кожній фірмі визначити ключові сфери діяльності КСВ та побудувати стратегію соціальної відповідальності бізнесу. 


\section{Список використаних джерел}

1. Adamczyk J. Społeczna odpowiedzialność przedsiębiorstw. Teoria i praktyka. Warszawa: Polskie Wydawnictwo Ekonomiczne, 2009.

2. Bartkowska M., Galkowski J. Etyka w biznesie. Lublin: Towarzystwo Naukowe, 2002.

3. Bierzanek R., Symonides J. Prawo międzynarodowe publiczne. Warszawa: Wydawnictwo LexisNexis, 2004

4. Carroll A.B. The Good Company. A Skeptical Look at Corporate Social Responsibility // The Economist. 2005, January.

5. Gasparski W., Jablońska-Bonca J. Biznes Prawo Etyka. Warszawa: Wydawnictwo Akademickie i Profesjonalne, 2009.

6. Karaszewski R. Przywództwo w środowisku globalnego biznesu. Toruń: Dom Organizatora TNOiK, 2008.

7. Paliwoda-Matiolanska A. Odpowiedzialność spoleczna w procesie zarządzania przedsiębiorstwem. Warszawa: Wydawnictwo C.H. Beck, 2009.

8. Segal J.P., Sobczak A. Triomphe C.E. CSR and working conditions // J.P. Segal, A. Sobczak; Europejska Fundacja na rzecz Poprawy Warunków Życia i Pracy, 2003.

9. Snihur S. Etyka Biznesu. Warszawa: Wydawnictwo SGGW, 2006.

10. Яременко В., Сліпушко О. Новий тлумачний словник української мови. Кніів: Видавництво "Акоиіт", 2004.

$$
\begin{array}{r}
\text { К. БОРИЦКИЙ, } \\
\text { магистр делового администрирования, } \\
\text { генеральньй директор ООО "Bеnteler Distribution Poland", } \\
\text { г. Домброва-Гурнича, Польиа }
\end{array}
$$

\section{Теоретические основы социальной ответственности предприятия}

В статье раскрыты теоретические основы социальной ответственности предприятия, рассмотрена трактовка термина «сочиальный». Проанализированы модели социальной ответственности предприятия и системы социальной ответственности. Доказано, что схема сочиальной ответственности предприятий будет работать эффективно и содействовать реализации иелей организации, если она будет иметь черты открытой системы, которой свойственно взаимодействие с окружсающей средой. Вместе с тем, в соответствии с системным направлением современных теорий управления, воспринимая предприятие как однородную, целевую систему, следует помнить, что все внутренние действия, проходящие в одном элементе системь, будут иметь последствия для других ее элементов.

Ключевые слова: бизнес, корпоративная сочиальная ответственность, модель сочиальной ответственности, предприятие, стратегия.

K. BORYCKI,

Master of Business Administration, General Director of "Benteler Distribution Poland" Ltd, Dabrowa-Gornicza, Poland

\section{Theoretical Foundations of Corporate Social Responsibility}

The article 's objective is to reveal theoretical foundations of corporate social responsibility. It is argued that the financial crisis and its implications for the global economy have demonstrated once and again that stability of the global market is conditional on the responsible behavior, models of balanced business operation, active management, impact of business (companies) on the social life, and regulatory framework. The global corporate social responsibility depends on problems associated with change in the global climate and deepened social inequality. The demand for social policy is tremendous at global and sectoral level.

Business needs to be engaged in social issues because a new global social contract between business, government and society is required to ensure long-term stabilization and reproduction of wealth. It has become even more obvious at corporate level. 
It is shown that the notion of "social" has many meanings, but in the legal context it means the need to account, apart from the literary meaning of this norm, for the social context in which this norm operates. The notion "social" is synonymous to society, referring to not only business operation target but also to the responsibility of a businessman.

It is demonstrated that the corporate social responsibility will work effectively and help achieve the organizations' objectives if it has the parameters of an open system interacting with the environment. At the same time, it should be remembered that in keeping with the system characteristic of modern management theories addressing a company as a homogenous and target-oriented system all the internal processes occurring in one component of this system will have effects for its other components.

Keywords: business, corporate social responsibility, model of social responsibility, company, strategy.

\section{Посилання на статтю:}

Борицький К. Теоретичні основи соціальної відповідальності підприємства // Науковий вісник Національної академії статистики, обліку та аудиту: зб. наук. пр. 2017. №3. С. 47-54. 